\title{
ALIGNING FRAMES FOR ELEPHANT EXTINCTION: TOWARDS A NEW ROLE FOR THE UNITED NATIONS
}

\author{
André Nollk:aemper*
}

Editor's Note: This post is based on an ESIL Reflection, Framing Elephant Extinction ${ }^{1}$, vol. 3, issue 6.

\section{Introduction}

The development of rules and institutions relating to protection of elephants demonstrates the cardinal role of issue framing for international law. Frames are lenses that we use to highlight parts of reality and to promote particular policies over others. Over the past few decades, a wide variety of treaties and institutions addressing threats to elephants has developed, reflecting as wide a variety of frames. Some of these have helped elephants more than others.

In colonial times, Western powers saw the elephant as a species that needed to be protected to provide hunters with trophies and to secure ample amounts of ivory. This led to the 1933 Convention Relative to the Preservation of Fauna and Flora in the Natural State, ${ }^{2}$ which restricted hunting of elephants with tusks under five kilograms (eleven pounds). Paradoxically, the hunting frame saw elephants as a species that needed to be protected in order to be killed.

The hunting frame has been overtaken by a variety of more modern frames, each inducing different forms of regulation. The biodiversity frame attaches value to the survival of the species as a whole. The crime frame construes elephant poaching as a problem that belongs in the list of human trafficking, narcotics and corruption, challenging states, and social welfare. The security frame sees poaching as a source of funding for weapons of armed groups that threaten security across states. The development frame sees elephant extinction as a problem that is part and parcel of the quest for land, resources, and development.

Distinguishing between these frames is not a sterile analytical exercise. Despite decades of international regulation, elephant extinction is a realistic prospect. According to a report ${ }^{3}$ released by the Secretariat of the Convention on International Trade in Endangered Species of Wild Fauna and Flora (CITES), the number of elephants killed by poaching exceeds the natural population growth rates. Identifying different frames allows us to understand why particular regulatory attempts have been more effective than others. It also allows us to expose conflicts between regulatory approaches as well as prospects for synergies. As I outline below, frames impact the protection of elephants under international law with regard to selectivity, competition, and synergies. \footnotetext{
al Law.

Originally published online 1 Dec. 2014.

1 André Nollkaemper, Framing Elephant Extinction, 3 ESIL REFLECTION 6 (2014).

2 International Convention for the Protection of Fauna and Flora [with Protocol], Nov. 8, 1933.

3 Press Release, CITES, Elephant Poaching and Ivory Smuggling Figures Released Today (June 13, 2014).
}

* Professor of Public International Law at the Faculty of Law of the University of Amsterdam and President of the European Society of Internation- 


\section{Impact of Frames on Elephant Protection}

First, each of the above frames is limited in scope and as such "misframes" a complex reality. The biodiversity frame has nothing to offer for security and little for development. Conversely, the security frame neglects habitat loss due to human expansion and land conversion, even though the Living Planet Report $2014^{4}$ documents that habitat loss is almost as significant a cause of species extinction as exploitation. It has been projected ${ }^{5}$ that by 2050, 63 percent of the existing elephant range will be affected by infrastructure development, human population growth, and urban and agricultural expansion, particularly in West, Central, and Eastern Africa. Seen in that light, effective Security Council action may help to make an area secure, but it may not save the species. Somewhat cynically, extinction would even enhance security, as it would render ivory unavailable to finance arms.

Second, frames compete. It may be rare that a particular approach to elephant protection conflicts outright with another. However, we can witness a more hidden competition. Framing poaching in one way, and building consensus on the basis of that frame, may move the spotlight away from other considerations, even when these are critical to survival of the species. For instance, framing wildlife issues as a security problem may shift momentum away from the negotiation of the post 2015 development agenda. Such a "securitization of development" may adversely affect policies aimed at poverty reduction in states less associated with security threats. This may have potential negative consequences for wildlife protection-after all, poverty is a key cause of poaching. ${ }^{6}$ More generally, the current attention on crime and security aspects of poaching may function to protect the power of existing regimes, even when these may have shown little inclination to use their powers to protect elephants.

Third, in other instances, frames can be aligned, leading to synergies between regulatory approaches. Some frames have been significantly more powerful in securing support for effective regulation than others. The biodiversity frame in itself has not been able to propel an international consensus for effective regulation. Characterized by weak enforcement in many key states, CITES has not been able to stem the tide. However, the recognition of the involvement of organized criminal networks in poaching has raised the stakes and has strengthened international support for combating poaching, for instance in the United Nations Convention against Transnational Organized Crime and the Global Programme for Combatting Forest Crime, ${ }^{7}$ adopted under the auspices of the UN Office on Drugs and Crime (UNODC). Even more powerful is the synergy with security. The security frame induced the Security Council to impose, in Resolutions $2134^{8}$ and 2136, ${ }^{9}$ travel and financial sanctions on individuals and entities that engage in illicit exploitation of wildlife and wildlife products, fueling conflicts in the Central African Republic and the Democratic Republic of Congo. These resolutions go beyond what could be achieved by CITES. Whoever succeeds in attaching the security label to the protection of any interest, gains significant momentum in triggering effective action.

\footnotetext{
${ }^{4}$ Living Planet Rep. 2014: Species and Spaces, People and Places, World Wide Fund For Nature [WWF] (2014).

5 Elephants in the Dust:The African Elephant Crisis, CITES \& U.N. Environment Programme (2013).

${ }^{6}$ Paula Kahumbu \& Andrew Halliday, The War on Poaching Cannot be Won in the Field Unless We Take on High-Level Corruption, THE GUARDiAN (May 5, 2014).

${ }^{7}$ UNODC Adopts New 'Global Programme for Combating Wildlife and Forest Crime', UN OfFICE ON DRUGS AND CRIME [UNODC] (May 21, 2014).

${ }^{8} \underline{\text { SC Res. } 2134}$ (Jan. 28, 2014).

9 $\underline{\text { SC Res. } 2136}$ (Jan. 30, 2014).
} 


\section{Aligning Frames}

In view of the limitations of individual frames, the hidden competitions between frames, and the potential for synergies, it is on good grounds that there is increasing support for an "alignment" of frames. Such support for a more integrated approach to the problem of poaching and illicit wildlife trafficking was expressed by 46 states at the 2014 London Conference Declaration on Illegal Wildlife Trade ${ }^{10}$ and at a high-level panel discussion, ${ }^{11}$ sponsored by Gabon and Germany en marge of the General Assembly.

Of course, calling for integration is easier than securing it. Aligning frames is far from a neutral exercise. Effective elephant protection is not just a matter of piling up different frames and regulatory approaches. Frames are selected by particular actors with particular agendas and particular bases of power. Any attempt at a more integrated approach will expose intricate political choices as to what and who international law should and should not protect. Should international law support the interests of the species, humans in their quest for development, or societies that suffer from armed conflict? Or should it protect individual elephants as such, irrespective of concerns over biodiversity, crime, security, or development, based on an animal rights frame that so far has failed to make an impact on the discussions? Moreover, as indicated above, opting for one frame may weaken another.

The trade-offs become much more complicated when more fundamental causes of elephant extinction are taken into account. Taking sanctions against poachers who kill for ivory so as to finance arms only scratches the surface of the problem. Measures that address the root causes of the poaching problem, that curtail demand, that set aside land areas where species can effectively be protected, that do so in a way that it can be reconciled with ruraland urban development in "the global South," and that incorporate the responsibility of "the global North" are infinitely more difficult to agree on. While protecting elephants may seem a narrow topic, it nonetheless involves big political decisions on development and security, and tradeoffs between them. It is noteworthy that both the 2014 London Conference Declaration on Illegal Wildlife Trade ${ }^{12}$ and the recent high-level panel discussion ${ }^{13}$ in New York focus much more on the poaching, crime, and trade aspects than the even more complex questions of land use and development.

\section{Moving Forward: A Greater Role for the United Nations}

The obvious step forward therefore is to create a process and an institutional set-up that will allow for articulation and confrontation of these various interests, and that will facilitate consensus building on concrete steps forward. Moving forward with elephant protection first and foremost is a matter of connecting regimes and institutions, and of identifying the possibilities for frame alignment. None of the existing institutions is well positioned to provide a forum to implement such proposals. The mandates of CITES, UNODC, and so on are limited. Once an institution has been set up, the law freezes and limits the frame.

To some extent institutions have engaged in collaboration, notably in the International Consortium on Combating Wildlife Crime, ${ }^{14}$ which provides a forum for cooperation between the CITES Secretariat,

${ }^{10}$ London Conference Declaration on Illegal Wildlife Trade, Feb. 13, 2014 (on file with U.S. Dep't of State, U.S. Embassy, IIP Digital).

${ }^{11}$ High-level Panel Discussion: "Poaching and Illicit Wildlife Trafficking - A Multidimensional Crime and a Growing Challenge to the International Community", UN GA side event hosted by Germany and Gabon (Sept. 26, 2013).

12 See London Conference Declaration on Illegal Wildlife Trade, Feb. 13, 2014 (on file with U.S. Dep’t of State, U.S. Embassy, IIP Digital).

13 See High-level Panel Discussion: "Poaching and Illicit Wildlife Trafficking - A Multidimensional Crime and a Growing Challenge to the International Community", UN GA side event hosted by Germany and Gabon (Sept. 26, 2013).

14 See Letter of Understanding Establishing the International Consortium on Combating Wildlife Crime (signed Nov. 23, 2010). 
INTERPOL, UNODC, the World Bank, and the World Customs Organization. However, this is still a narrow approach, as it does not encompass questions of habitat protection, development, and security. If we are to move beyond individual frames and beyond the limits of existing institutions charged with aspects of elephant protection, it would seem that the United Nations has a key role to play. All aspects of the problem, ranging from species protection per se, to development, crime, and security are squarely within its mandate. To involve the United Nations at the highest level and with the urgency that is required, it would be desirable to shift the discussion to the General Assembly. The General Assembly could articulate the various interests, adopt a broader agenda, and drive forward the political debate and regulatory integration of the various conservation, development, crime, and security frames. But the UN involvement cannot be limited to incidental GA resolutions. A Special Representative to the Secretary General (an idea proposed by Gabon and Germany ${ }^{15}$ ) could ensure more continuous action. (S)he could, on a more continuous basis than the Security Council or the General Assembly, leverage support beyond the narrow security agenda, strengthen institutional linkages, and seek to further cross-sectoral implementation of international commitments.

In this way, the United Nations could provide for a common political platform where frames can communicate, tensions can be articulated, and synergies may be found. The elephant may be well served if the "securitization" of its extinction would trigger broader normative and institutional development, embracing all frames holistically while taking into account potential trade-offs between the different frames that may arise.

${ }^{15}$ Letter dated Oct. 28, 2013 from the Permanent Reps. of Gabon and Germany to the United Nations addressed to the SecretaryGeneral, UN Doc. A/68/553 (Oct. 28, 2013). 